\title{
Images of Christ's Saving Work in Ps.-Epiphanius' Homilies
}

\author{
H F Stander \\ Department of Ancient Languages \\ University of Pretoria
}

\begin{abstract}
Images of Christ's Saving Work in Ps.-Epiphanius' Homilies

One cannot really speak of a systematic theology on the subject of atonement in the patristic writers. Frances Young once said that it is in fact impossible to categorize neatly the thought of the major patristic writers on the subject of atonement'. She adds that one cannot do justice to the range of motifs and images that are found in describing the saving and atoning work of Christ if we merely dismember 'systematic theologies' to illustrate common soteriological themes. One can only appreciate patristic views of atonement if one begins by recognizing the multifaceted unity of imagery that pervades the literature. This then is the goal of this article: to discuss the rich images which Ps:-Epiphanius uses to describe the atoning work of Christ.
\end{abstract}

\section{INTRODUCTION}

One cannot really speak of a common 'system' or 'theory' of atonement in the patristic writings. Young (1997:147) says that 'it is in fact impossible to categorize neatly the thought of the major patristic writers on the subject of atonement ${ }^{1}$ '. Yet, the teaching of salvation was important and it was everywhere presupposed. Wiles (1966:321-325) is one of the scholars who has pointed out the significance of this 'doctrine'. He shows that the Trinitarian and Christological debates were all related to soteriological concerns. He argues that 'the most fundamental reasons for the rejection of Arianism and Apollinarianism were soteriological reasons'. Apollinarianism, for instance, was rejected since 'the Apollinarian Christ was not fully human and not being such could not bring salvation effectively to the real point of human need'.

But Young (1987:107-114; 1997:143-148) says that one cannot do justice to the range of motifs and images that are found in descriptions of the saving and atoning work of Christ, if we merely dismember 'systematic theologies' to illustrate common soteriological themes. She also argues that one can only appreciate patristic views of atonement if one begins by recognizing the richness of typology and allegory, as well as the multifaceted unity of imagery that pervades the literature. 
It should also be noted at the outset that imagery can take on various forms such as comparisons, metaphors and symbols. These forms of imagery can be used in various theological approaches. They can, for example, be used typologically or allegorically. But all these forms of imagery are part of the tropological nature of religious language and are used to refer to figurative or nonliteral interpretation. Imagery is used when earthly and visible realities are interpreted symbolically to refer to heavenly realities. The goal of this article then is to discuss the rich images which Ps.-Epiphanius uses to depict the saving work of Christ, and to appreciate the rhetorical skill with which he employs these images.

In what is to follow, it may be argued that I do not always clearly distinguish between 'atonement', 'soteriology', 'salvation', 'expiation', 'redemption', et cetera. But again, I will do injustice to the Fathers if I try to dogmatically explain these concepts, make neat distinctions between them, and define a doctrine of salvation. In patristic literature all these themes were interwoven. For the ancient theologians the incarnation, for example, equalled the redemption, since the human nature was sanctified, transformed, 'divinized' and elevated by the very act of Christ's becoming man. As the title of this article suggests, I have therefore decided to use a very generic phrase, namely 'the saving work of Christ', in order to cover all the issues above.

\section{PS.-EPIPHANIUS AND HIS WORKS}

Just a short word on the five festal sermons ${ }^{2}$ which have been preserved under the name of Epiphanius. Though we can be certain that Epiphanius was not the author of these homilies, the contents thereof suggest that the author must have been a contemporary of Epiphanius and probably lived in the same regions. We do know that Epiphanius (315-403) was a native of Palestine and became bishop of Salamis in Cyprus.

\section{IMAGES}

We will now look in detail at Epiphanius' use of metaphors, extended images, allegory, typology and other images when he wants to highlight Christ's saving work:

\subsection{Metaphoric names of Jesus}

Ps.-Epiphanius uses numerous 'names of Jesus' to describe Christ's saving work.

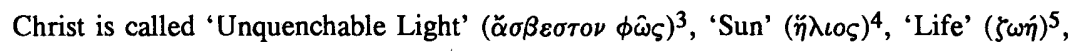
'Bridegroom' ( $\nu v \mu \phi i o \varsigma)^{6}$, 'Door' ( $\left.\theta \dot{v} \rho \alpha\right)^{7}$, 'Mountain' (ǒ $\left.\rho \varsigma\right)^{8}$, 'Palm of Righteous-

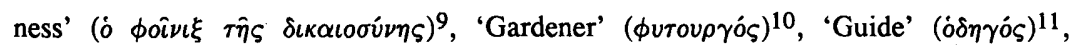




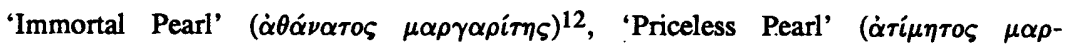
$\gamma \alpha \rho i \tau \eta)^{13}$, 'Heavenly Pearl' (oijónlos $\left.\mu \alpha \rho \gamma \alpha \rho i \tau \eta \varsigma\right)^{14}$, 'Glorious Lightning'

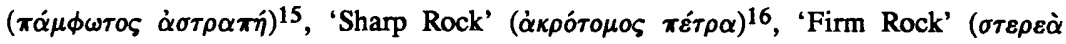

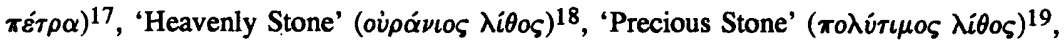
'Corner-stone' ('́)

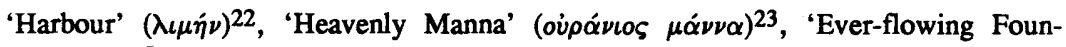

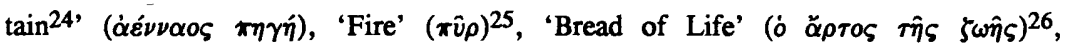

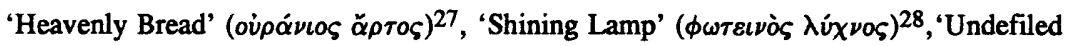

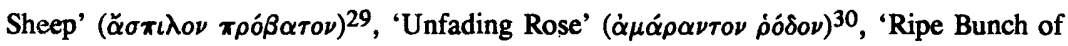

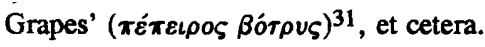

Each of these titles focuses on one aspect of Christ's atoning work, and almost everyone is backed up by a scriptural reference. But Ps.-Epiphanius does not merely list these titles which are so rich in theology. He often employs all his rhetorical skills when he elaborates on these titles. When he refers to Christ as a Lily (кpivov), he

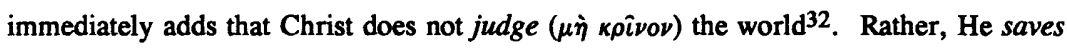

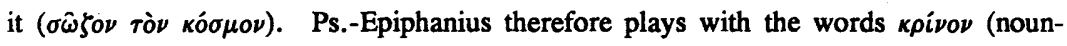

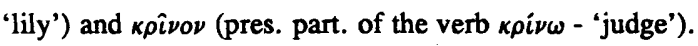

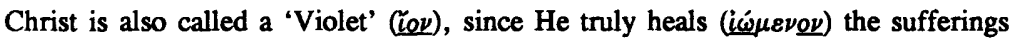

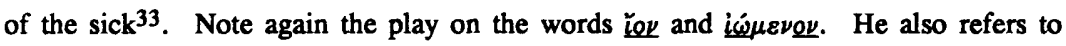

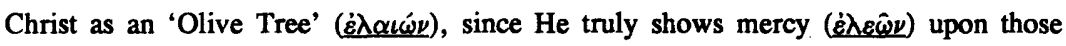
who trust in $\mathrm{Him}^{34}$. Again we have wordplay: $\dot{\varepsilon} \lambda \alpha \iota \dot{\omega} \nu$ and $\dot{\varepsilon} \lambda \varepsilon \hat{\omega} \nu$. Moreover, these two words were pronounced similarly in the times of Ps.-Epiphanius. All these names which are given to Christ focus on His redemptive work: He does not judge us, He heals us and He shows mercy upon us.

\subsection{Extended images (for example the parable of the lost sheep)}

Ps.-Epiphanius employs the parable of the lost sheep (Mt 18:10-14; Lk. 15:3-7) to describe in symbolic language how Christ redeemed us from the desperate situation in which we had found ourselves ${ }^{35}$. The Shepherd left the other ninety-nine sheep grazing on the hill-side. This refers to the angels who were left in heaven when Christ descended to redeem us. Christ found the lost sheep ( $=$ us) choked by the mud of life. He pulled us out of the mud with the right hand of his divinity. But, of course, we were then dirty. Christ therefore washed us with his compassion in the streams of the Jordan. And because we were smelling, He also anointed us with the fragrance of his Holy Ghost. Christ then carried the spiritual sheep on his shoulder of love to the heavenly haven. 


\subsection{Allegorical interpretation of the Passion Events}

Our redemption was accomplished by Christ's death on the cross. But Ps.-Epiphanius also uses the Passion events as allegorical images of the redemptive work of Christ ${ }^{36}$ : Jesus was slapped in the face in order to restore our face/form to its original state, when He created man in his own image; He received blows on his back, in order to remove our sins from our backs; because our feet ran to the tree of disobedience, his feet were nailed to a cross; Jesus tasted gall, and with the 'sweetness' thereof He healed us from the 'bitter' taste of our 'pleasure'; and by tasting vinegar, He removed the bitterness of death. People filled a sponge with wine vinegar, put it on a reed, and offered it to Jesus. But Jesus took a sponge and erased all our debts which were recorded in the $\chi \varepsilon \iota \rho$ ó $\rho \alpha \phi o \nu$ (record of debts). And then Jesus took the reed, and signed a statement granting freedom to people. In order to properly understand the latter two images, we should bear in mind that the ancients did in fact use a reed as a writing instrument, and a sponge as an eraser. These images therefore depict in a striking manner the saving work of Christ. We should rather appreciate and enjoy these metaphors, and refrain from trying to fit the early theologians' soteriological views into any doctrinal system.

\subsection{Typological use of Scriptures}

We have already quoted Young $(1987: 107 ; 1997: 47)$ who said that one can only appreciate the patristic views of atonement if one begins by recognizing the richness of typological and allegorical use of scripture. Ps.-Epiphanius uses Moses' life as a type of Christ's redemptive work and says as follows ${ }^{37}$ :

* Moses was sent by God to redeem the people, and Christ was sent by God to redeem us.

* Moses delivered the people from Pharaoh and the Egyptians, and Christ delivered us from the hands of Satan, and from the demons.

* Moses committed murder and he buried in the sand the one who wronged a Jew, and Christ killed the devil and then He gave him over to Hades.

* Moses reconciled his two brothers who were fighting, and Christ reconciled his two nations when He united the heaven with the earth. 
* The daughter of Pharaoh found Moses when she had gone out to bathe, and the Church (i.e. the daughter of Christ) receives Christ at baptism.

In the rest of this pericope Ps.-Epiphanius also points out the differences between the redemption effected by Moses, and the redemption effected by Christ. He then shows that the saving work of Christ supersedes the work of Moses. I will quote only a few examples:

* There Miriam danced when the people were saved, but now the Church of Christ celebrates when nations are saved.

* There the tablets of the law were broken by Moses indicating the violation of law, but now the laws of God are preserved unbroken.

* There a bull was melted to punish the people, but here the Lamb of God is sacrificed for the redemption of mankind.

* There the people received quails, but now we receive a dove (= the Holy Spirit).

* There the people ate perishable manna and died, but now we eat bread and receive eternal life.

\subsection{Images of Christ's victory over death and Satan}

\subsubsection{Victory over Death}

Elsewhere ${ }^{38}$ Ps.-Epiphanius refers to Christ's descent to Hades and he assigns a symbolical and figurative interpretation to this event also. He uses it as an image of how Christ redeemed us from Death's hold on us. He says that Christ, who is our 'Door' $(\theta \dot{v} \rho \alpha)$, destroyed the doorless ( $\dot{\alpha} \underline{\theta} \underline{v} \rho u \varsigma)$ entrance $(\underline{\theta \dot{v} \rho} \alpha \varsigma)$ of Hades when He had broken down the woodless ( $\dot{\alpha} \xi \hat{v} \lambda \circ v_{\varsigma}$ ) doors by the wood ( $\left.\xi \dot{v} \lambda \omega\right)$ of the cross. With divine nails $\mathrm{He}$ broke the bolt placed across the gates and with the handcuffs of his

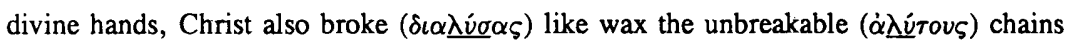
( $\dot{\alpha} \underline{\hat{v} \sigma} \varepsilon \iota \varsigma$ ) of our bondage [note the pun]. But the next image is even more striking: Christ shattered the powers of the bows of the foe, when He stretched his hands on the cross like the string on a bow. 


\subsubsection{Victory over Satan}

\subsubsection{A hawk and chickens}

Striking images are used to describe Christ's victory over Satan: Christ is depicted as a swift-flying hawk ${ }^{39}$. Just as a hawk snatches away the chickens from a bird, Christ snatched away all the dead who were under Satan's power, and left him destitute. Moreover, Christ then also clipped Satan's wings from every side, and then He threw him down onto the earth.

\subsubsection{The chariot-race}

Many early theologians believed that our nature was redeemed when Christ took back our nature to the presence of God. When Christ therefore ascended to God through all the different levels of heaven, together with our redeemed humanity, Satan made a final attempt to hinder Him from doing it. Ps.-Epiphanius then uses the chariot-race as an image ${ }^{40}$. He says that those who frequent chariot races, and those who love to watch the speed of the chariot drivers, would enjoy to watch this contest between Satan and Christ. Christ was riding upon a human chariot (i.e. our human nature) on heavenly courses. He was driving forward to reach the heavenly turning-point. However, when He came alongside Beliar ${ }^{41}$ (= the devil), He powerfully overturned him!

\subsubsection{Plumb-line and a stone from a sling}

Elsewhere ${ }^{42}$ Ps.-Epiphanius again gives a vivid description of Satan's struggle to overturn the work of the Redeemer: When Satan saw Christ ascending to heaven, he wanted to bring Him down like a plumb-line. Christ, however, threw him down like a very heavy stone as from a sling. The image is probably based on the assumption that a heavy stone which is cast by a sling falls much harder onto the ground than a plumbline. The image is therefore used to state that Christ managed to successfully ward off Satan's assault.

\subsubsection{Bait and a fish-hook}

Some of the images used by Ps.-Epiphanius are unique and are to be found only in his writings. Other images are quite common and are frequently found in patristic literature. Ps.-Epiphanius, for example, addresses the Virgin Mary and says: 'You are the bait of the spiritual fish-hook, for in you the Divinity is the hook' (

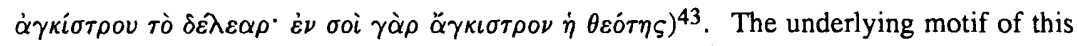


image is well-known and is discussed elsewhere by Ps.-Epiphanius ${ }^{44}$, but also by several other early Christian writers. Gregory of Nyssa, for example, discusses how God deceived the devil. Gregory argues that since mankind fell into the devil's clutches through his own free choice, the Devil had therefore the right to proper compensation if he were to surrender mankind. So God offered Jesus to the devil. When Satan saw Jesus who was born of a virgin, he decided that the exchange was to his advantage. But the devil failed to see that the Deity was hidden under the veil of our human nature. Hence, when the devil accepted Jesus in exchange for mankind, he could not hold him. He was outwitted and caught, as a fish is by the bait which conceals the hook ${ }^{45}$. Gregory of Nyssa says that the Deity was hidden under the veil of our nature so that the hook of the Deity might be gulped down along with the bait of the flesh and thus life be introduced into the house of death, and light shining in the darkness, in order that that which is diametrically opposed to light and life might vanish ${ }^{46}$.

\section{The effect of Christ's Saving work}

\subsection{Synagogue versus Church}

The redemption of Christ conferred many benefits upon believers and the Church. Ps.Epiphanius says as follows:

$\pi \dot{\alpha} \lambda \iota \nu \dot{\eta} \dot{\varepsilon} \kappa \kappa \lambda \eta \sigma i \alpha$ Хopeviel,

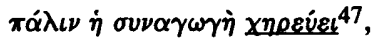

(again the Church dances)

(again the synagogue is like a widow)

The images of a dancing Church versus a synagogue who has lost her husband (bridegroom) beautifully illustrate the effects of Christ's redemption on these two institutions. Note also the homilist's clever use of two similar-sounding verbs to highlight this truth.

\subsection{The Church likened to the sky}

Ps.-Epiphanius also says that because of the work of the Sun of righteousness (= Christ), the Church became like the $s k y^{48}$. However, the Church as sky supersedes the sky we know. In the first place the sun of the sky sets every day, but the Sun of righteousness always shines on those who fear Him. Moreover, the sky has a waning and waxing moon, but the Church has the ever-shining grace of God. The sky has a few wandering stars rising up, but the Church has newly illuminated stars (= baptismal candidates) rising up from the baptismal font. The sky has rain-bringing clouds, but 
the Church has teachers who teach about God. (In early Christian literature and art the watering of the earth was frequently seen as a symbol of the teaching of the gospel to all people.) Ps.-Epiphanius continues to depict the Church as the sky and says that the sky was suspended from troubled waters above, but the Church is founded upon holy doctrines. Neither would the Church send out winter-storms. (The underlying idea is probably that the Church does not cause hardship to people, as the sky does.) The sky has the sounds of birds, but the Church has the voices of teachers.

\subsection{The effect on pagans and Jews}

Ps.-Epiphanius uses puns and rich images when he describes the effect of Christ's saving work among both pagans and Jews ${ }^{49}$. He firstly deals with the Jews, and thereafter with the pagans. Concerning the Jews, Ps.-Epiphanius says that:

* in their sinful state they were like a widow ( $\chi \dot{\eta} \rho \alpha \nu \delta \rho o \varsigma=$ deprived of a husband), but because of Christ's atoning work, they have become a bride of God ( $\theta \varepsilon \alpha \nu \delta \rho \circ \varsigma$ ) - note the wordplay.

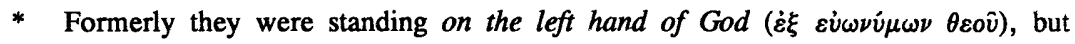
Christ changed their position and now they stand on the right hand of God ( $\dot{\varepsilon} \kappa$ $\delta \varepsilon \xi \iota \hat{\omega} \nu)$.

* Formerly they were defiled with the blood of slavery ( $\alpha \check{\iota} \mu \alpha \tau \iota \delta o v \lambda \iota \kappa \hat{\varphi} \phi v \rho \omega \mu \varepsilon \dot{\varphi} \nu)$,

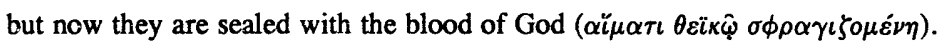

* Formerly they worshipped $\mathrm{Bel}^{50}$ (B $\dot{\eta} \lambda$ - the Akkadian deity), but now they worship Emmanuel ('E $\mu \mu \alpha \nu o v \eta \dot{ } \lambda$ ) - note again the wordplay.

All these images have a rich Biblical background. The image of the bride of God, for example, is based on the Old Testament depiction of Israel as the wife of God (cf. Isa. 54:6 and Ezek. 16:8).

Some of the most beautiful examples of paronomasia are found in the second section where Ps.-Epiphanius describes the effects of Christ's atoning work among the pagans. Because of Christ's victory (i) the pagans no longer glorify T $\rho \omega \alpha \dot{\alpha} \delta \alpha$ (= Troy), but the T $\rho \iota \alpha \delta \alpha$ (= Trinity). (ii) No longer do they honour $\Pi \lambda \alpha \dot{\alpha} \omega \nu \alpha$ (= Plato), but rather $\tau \dot{\nu} \nu \pi \alpha \nu \tau о \kappa \rho \alpha ́ \tau o \rho \alpha \theta \varepsilon \dot{\nu}$ (= the almighty God). (iii) No longer do they worship 'H $\alpha_{\alpha \kappa \lambda \hat{\eta}}$ (= Heracles), but rather the $\Pi \alpha \rho \underline{\alpha} \kappa \lambda \eta \eta \bar{\eta}$ (= Paraclete). (iv) No longer do 


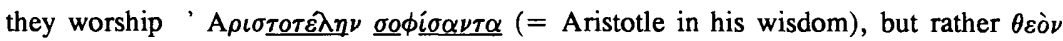
$\tau \grave{\partial} \nu \varepsilon i \varsigma \tau \varepsilon \lambda \eta \eta \hat{\omega} \nu \alpha i \omega \omega \omega \nu \sigma \varepsilon \sigma \dot{\omega} \sigma \alpha \nu \tau \alpha$ (= God who has saved you till the end of the ages). The very last word of this section, namely $\sigma \dot{\omega} \sigma \alpha \nu \tau \alpha$ (= saved), functions as a climax of this whole stylized section dealing with the soteriological work of Christ.

\section{Conclusions:}

* Though the Fathers never treated the theme of soteriology systematically, they used colourful images and symbolic language to depict Christ's saving work. Attempts to search early patristic literature for theories and doctrines on any aspect of atonement, are destructive of the Fathers' imaginative vision. We must also add that behind the symbolic language there is nevertheless a synthesis as well as an underlying 'system', but attempts to 'translate' these symbols into a doctrine are doomed. Therefore I think Young is correct when she says that 'maybe our culture has become so impoverished in the matter-of-factness of science and history that we can never do justice to the 'tropological' character of religious language'.

* Brock (1990:40) says that 'St Ephrem's mode of theological discussion ... stands in sharp contrast to the dogmatizing approach which, under the influence of Hellenic philosophy, has characterized much of the Christian theology with which we are today familiar'. He adds that 'it is precisely because Ephrem's theology is not tied to a particular cultural or philosophical background, but rather operates by means of imagery and symbolism which are basic to all human experience, that this theological vision, as expressed in his hymns, has a freshness and immediacy today that few other theological works from the early Christian period can hope to achieve'. Although Brock confirms our point of view, he is mistaken in seeing the use of imagery and symbolism as characteristic of the writings of St Ephrem only. When one reads the works of homilists of the fourth century, such as Ps.-Epiphanius, one finds that imagery is a significant feature of their writings also.

* Ps.-Epiphanius' use of images is very successful. It would also be very interesting to study in detail the characteristics of effective images, and to find out in what respects Ps.-Epiphanius succeeds in complying with these requirements. But this would be a study on its own.

* Finally, the works of Ps.-Epiphanius have for a long time been neglected by scholars. This is very unfortunate since these homilies are fine examples of the homilies stemming from the school of Antioch. It is therefore hoped that this article will 
again bring to the fore these homilies, which are rich in theology, and which were written with so much rhetorical skill.

\section{Endnotes}

1 See also Young (1987:107-114), Kelly (1977:375) \& Studer (1978:57).

2 For the text, see MPG 43.428-502.

3 Hom. 5 (MPG 43.497B); Cf Hom. 5 (MPG 43.493D).

4 Hom. 2 (MPG 43.440C); Hom. 5 (MPG 43.497C).

5 Hom. 1 (MPG 43.429B).

6 Hom. 1 (MPG 43.429A).

7 Hom. 2 (MPG 43.456A).

8 Hom. 3 (MPG 43.468C).

9 Hom. 1 (MPG 43.429D - Footnote 62).

10 Hom. 1 (MPG 43.437B).

11 Hom. 1 (MPG 43.437B).

12 Hom. 5 (MPG 43.489A).

13 Hom. 2 (MPG 43.444D).

14 Hom. 5 (MPG 43.489D); Cf Hom. 5 (MPG 43.496C).

15 Hom. 5 (MPG 43.492B); Cf also Hom. 5 (MPG 43.492D).

16 Hom. 5 (MPG 43.492D).

17 Hom. 5 (MPG 43.492D); Cf also Hom. 2 (MPG 43.440B).

18 Hom. 5 (MPG 43.492D).

19 Hom. 5 (MPG 43.496B).

20 Hom. 2 (MPG 43.440B); Cf also Hom. 2 (MPG 43.441C).

21 Hom. 2 (MPG 43.440B).

22 Hom. 4 (MPG 43.489A).

23 Hom. 5 (MPG 43.489D);

24 Hom. 5 (MPG 43.489D); Hom. 1 (MPG 43.432A).

25 Hom. 5 (MPG 43.492D; 493D; 496A).

26 Hom. 5 (MPG 43.492D; 493B; 496A).

27 Hom. 5 (MPG 43.497A).

28 Hom. 5 (MPG 43.496A).

29 Hom. 5 (MPG 43.493B).

30 Hom. 5 (MPG 43.496D).

31 Hom. 5 (MPG 43.496D).

32 Hom. 1 (MPG 43.432A).

33 Hom. 1 (MPG 43.432A).

34 Hom. 1 (MPG 43.432A).

35 Hom. 4 (MPG 43.481B).

36 Hom. 2 (MPG 43.461C-464A).

37 Hom. 3 (MPG 43.468C-469C).

38 Hom. 2 (MPG 43.453D-456C).

39 Hom. 4 (MPG 43.481C).

.40 Hom. 4 (MPG 43.480C-480D). 


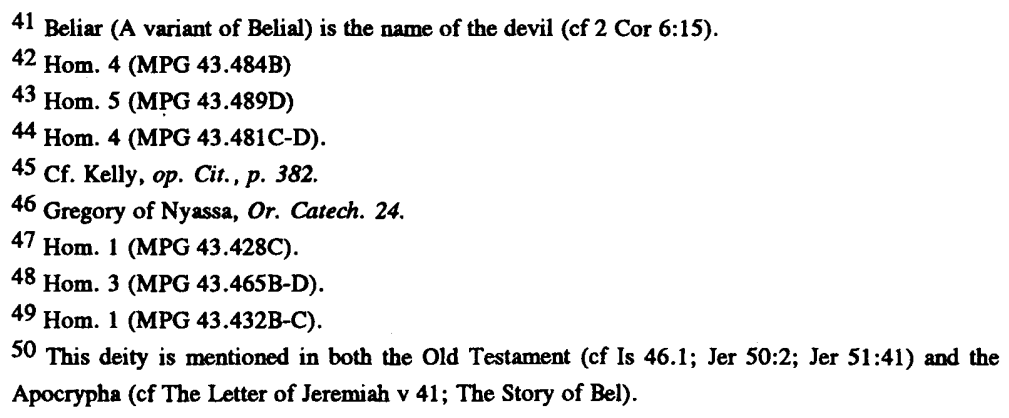

\section{Works consulted}

Aulen, G 1931. Christus Victor. London: SPCK.

Brock, S 1990. Saint Ephrem: Hymns on Paradise. New York: St Vladimir's Seminary Press.

Kelly, J N D 1977. Early Christian Doctrines. London: Adam \& Charles Black.

Lyonnet, S \& Sabourin, L 1970. Sin, Redemption, and Sacrifice: A Biblical and Patristic Study. Rome: Biblical Institute Press.

Rivière, J 1909. The Doctrine of the Atonement: A Historical Essay (2 vols.). London: Kegan Paul, Trench, Trübner \& Co. Ltd.

Studer, B 1978. Soteriologie in der Schrift uns Patristik. Freiburg: Herder. (Handbuch der Dogmengeschicte, Band III, Fas. 2a)

- 1992. 'Soteriology', Encyclopedia of the Early Church, edited by A Di Berardino 788-789. Cambridge: James Clarke \& Co.

Turner, H E W 1952. The Patristic Doctrine of Redemption. London: Mowbray.

Wiles, W F 1966. Soteriological arguments in the Fathers. Studia Patristica 9, 321325.

Young, F M 1987. Allegory and Atonement. Australian Biblical Review 35, 107-114.

- 1997. s v Atonement. Encyclopedia of Early Christianity. New York: Garland Publishing, Inc. 